\title{
RELATIONSHIP OF FORMER HISTORY OF DIARRHEA AND SANITATION WITH THE PREVALENCE OF STUNTING AMONG CHILDREN AGED 1-5 YEARS IN SIDOTOPO WETAN, SURABAYA
}

\author{
Naisya Azalia Samsuddin ${ }^{1, *}$, Emyr Reisha Isaura ${ }^{1,2}$, Sri Sumarmi $^{2}$ \\ ${ }^{1}$ Study Program of Nutritional Science, Department of Nutrition, Faculty of Public Health, Universitas Airlangga, Surabaya \\ ${ }^{2}$ Public Health Study Unit, Faculty of Public Health, Universitas Airlangga, Surabaya \\ *E-mail: naisya.azalia.samsuddin-2016@fkm.unair.ac.id
}

\begin{abstract}
Stunting defines as an abnormal linear growth of children less than -2 standard deviations (SD) of the height measurements according to age. According to WHO (2013), the quality and quantity of nutrient intake and the presence of infectious diseases are directly associated with stunting, while hygiene and sanitation are indirectly associated with stunting. This study aimed to determine whether there is a relationship between disease history and sanitation with the incidence of stunting in children aged 1-5 years in the working area of Sidotopo Wetan Health Center (Puskesmas), Surabaya City. This cross- sectional study was used secondary data from the survey of Puskesmas Sidotopo Wetan children under five - supervising program 2020 which included 166 children aged $\leq 5$ years. The dependent variable was stunting, and the independent variables are the history of diarrheal disease and sanitation facilities. The results found that 77 children under five were stunting (46.40\%), history of frequent diarrhea was $19.26 \%$, history of the last one month of having diarrhea was $20.47 \%$, permanent healthy toilet ownership $89 \%$, and qualified trash bin were $46.97 \%$. The results of the chi-square statistical test on the research variables further showed a positive relationship with a history of frequent diarrhea $(p=0.023)$ and diarrhea during the past month $(p=<0.001)$ with the incidence of stunting. There was also a negative relationship between the toilet $(p=<0.001)$ and trash bin ownership with the incidence of stunting $(\mathrm{p}=0.023$ ). Thus, this study concludes that the history of diarrhea and environmental sanitation factors of toilet and trash bin ownership have a relationship with the incidence of stunting in children under five years old. The stunting prevention program shall more consider the awareness of the parents and their kids about nutrient intake, practice of hygiene and sanitation in the house.
\end{abstract}

Keywords: history of diarrhea, sanitation, stunting

\section{INTRODUCTION}

Stunting is abnormal linear growth in children. A child categorized as stunted if the measurement results of height according to age are less than

-2 standard deviation (SD) (WHO, 2010). The problem of stunting interprets the occurrence of chronic nutrition in the fetus, infants, and children under-five, as well as other indirect factors related to health issues (Pusdatin, 2016). Meanwhile, the direct cause of the incidence of stunting is lack of quantity of nutritional intake, as well as the presence of infectious diseases that occur over a long period of time or repeatedly, while the indirect causes include hygiene and sanitation (WHO, 2013).

The incidence of stunting is caused by food security at the household level, parenting, social, economic, and environmental conditions, including hygiene and sanitation. Meanwhile, the direct cause of stunting is a lack of nutritional intake of quality or quantity so that children's needs are not fulfilled, as well as the presence of infectious diseases that occur over a long time or repeatedly (UNICEF, 2013).

Based on data from the Surabaya City Health Profile, the percentage of children under five with stunting in Surabaya in 2018 was $8.92 \%$, of which was broken down into stunting of $2.04 \%$ and severe stunting of $6.88 \%$. The Basic Health Research of the Republic of Indonesia (Riskesdas) in 2018 regarding infectious diseases affirmed that diarrhea was one of the infectious diseases and was the leading cause of under-five children mortality with $12.3 \%$ (Riskesdas, 2018).

The 2018 survey results in Indonesia showed that households with access to proper sanitation were $74.6 \%$, which had been compared to the standard SDG's is only $7.47 \%$ qualifying 
proper sanitation (BAPPENAS, 2020). Besides, according to the 2018 Riskesdas data, in East Java, the proportion of households that discharged wastewater directly into the sewer flow either from bathroom or laundry and kitchen waste reached 53.2\% (Indonesia MoH, 2018).

According to the results of data analysis from the Indonesia Family Life Survey (IFLS), it was disclosed that an increase in sanitation factors is related to the risk of diarrhea infection in Indonesian children (Azhar, 2014; Patunru, 2015; Cronin, 2016). The results of other studies further showed that poor access to sanitation in types of unqualified toilets increases the risk of stunting by 1.3 times higher than those of babies under two years who use proper toilets (Adiyanti, 2014). These results thus confirmed that water and sanitation are the primary interventions to prevent stunting. Based on these findings, this study aims to determine the relationship between a history of diarrhea and sanitation facilities and the incidence of stunting in children aged 1-5 years.

\section{METHOD}

This study applied the cross-sectional research design carried out in Sidotopo Wetan Health Center, Surabaya City. The population in this study was children under five years in the working area of Sidotopo Wetan Health Center with exclusion criteria are incomplete data, congenital disabilities, chronic disease, and had undergone a Community Feeding Center (CFC) / Therapeutic Feeding Center (TFC). The sample of this study, however, was in the form of secondary data taken from the 2020 children under five monitoring database survey conducted by health center nutritionists. From a total of 651 data samples, 166 samples that met the assessment criteria for the study sample were obtained.

The independent variables in this study were a history of diarrhea and sanitation, including the ownership of healthy toilets and qualified trash bin, while the dependent variable was stunting. The stunting category, moreover, was based on the $\mathrm{z}$-score, namely height for age (height/age) of less than -2 standard deviation (SD) (WHO, 2010). The measurement of body length for undertwo-year children was carried out by utilizing an infantometer length board and a microtoise to measure the children under five s' height, the tools used have an accuracy of $0.1 \mathrm{~cm}$. The measurement was carried by the nutrition officer of Sidotopo Wetan Health Center Surabaya.

The data was collected using secondary data from the results of the 2020 children under five monitoring database survey conducted during January - February by health center nutritionists. Measurement of diarrheal data was obtained based on historical data from frequent infections and diseases experienced during the last one month, with the option: "fever, runny nose, cough, diarrhea, none, and other diseases" then classified into "diarrhea, other than diarrhea, and not sick". Data on toilet sanitation facilities, with options: "permanent healthy toilet, semi-permanent healthy toilet, public toilet, and open defecation". Data on waste bin facilities with the classification: "qualified, unqualified, and do not exist" (Surabaya City Health Office, 2020).

The statistical analysis with SPSS 20 software, furthermore, used the chi-square test for nominal data, while for ordinal and ratio data, logistic regression tests with a confidence level (CI) of $95 \%$ or $\propto=0.05$ was employed. This study, moreover, has passed the ethical review from the ethics committee of the Faculty of Dentistry, Universitas Airlangga, with certificate number: 214/ HRECC.FODM / IV / 2020 also approval from Surabaya Health Office and Sidotopo Wetan Health Center Surabaya.

\section{RESULTS AND DISCUSSION}

\section{Under-five Children Characteristics}

Based on table 1, it can be seen that the sample of under-five children with stunting was 77 (46.4\%) and 89 (53.6\%) for normal children. Most of the respondents aged more than two years old and female, but for under-five children who experienced stunting were mostly male (23.49\%). In a cohort study, furthermore, it was found that 6-24 months of age male infants had a twofold more significant risk of experiencing stunting compared to female infants (Medhin et al., 2010; Roscha et al., 2013). Male gross motor development is faster and less monotonous so that 
it requires more energy, the energy reserves used for children's growth will decrease thus escalate stunting risk (Setyawati, 2018)

Under-five children who experienced stunting in this study were mostly in the group of children over two years old, as many as 76 under-five children $(45.78 \%)$. This result is in line with the results of Maharani's research in 2018, which affirmed that 15 out of 25 children under five are stunted when they are five years old because it is a critical period of growth and they not receive breast milk as moved into the weaning phase; breast milk itself play roles as protection that supports the immune system so that they are at low risk. In addition, under-five children with 24 months of age have and have increased activity in their surroundings, develop and grow their children under five gross motor skills (Maharani, 2018). At this stage, some children under five experience several possibilities that result in a lack of intake and specific nutrients, decreased appetite, decreased sleep hours, and the risk of developing infectious diseases is high if the mother or nurse is lacking in hygiene and sanitation (Setyawati, 2018).

The number of families of under-five children in the entire sample of the stunting group was in small families, or the number of members was less than 4 . In brief, there were 44 under-five children (26.50\%) who came from small families and 45 under-five children from large families $(27,01 \%)$. Families with more than five children or more than eight family members can be at risk of stunting in children in their families (Fikadu, 2014; Kofuor, 2014). Additionally, under-five children who come from families with a large number of household members are 1.34 times more likely to experience stunting than children under five from families with sufficient household members (Oktarina dan Sudiarti, 2013). The number of family members does not guarantee the fulfillment of the nutritional status of each family member, the arrangement of food availability and distribution is even and balanced can reduce the risk of stunting (Fitri, 2010).

Most of the mothers had a status of housewives so that the mother had a direct role as caregivers for under-five children concerning the incidence of stunting $(p=0.001)$, one possible reason is education level mother that contribute to the stunting. Stay-at-home mothers will have a higher intensity in caring for their children under five. Therefore, they can control their feeding patterns and meet their intake needs so that optimal nutritional status can be achieved (Sari, 2017). For working mothers, nonetheless, a lot of time is consumed for work so that mothers do not have time to get information on children's growth (Nafi'ah, 2015).

Besides, most of the parents were still married or not single parents, namely $74(44.57 \%)$ for parents of under-five children with stunting and 88 (53.01\%) for parents of normal children.

\section{History of Diarrhea}

Table 2 revealed that diseases other than diarrhea had a high frequency and were often suffered by both normal and stunting. Children under five with a normal nutritional status more often experienced diarrhea, as many as 24 children under five $(14.45 \%)$, compared to the stunting children $(4.81 \%)$. The same phenomenon also occurred in the history of the disease in the last month, confirming that children under five with normal nutritional status had diarrhea as many as 27 children under five s $(16.26 \%)$. In contrast, only seven children under five $(4.21 \%)$ were stunted. In stunting children under five, moreover, there were more diseases besides diarrhea, such as fever, cough, colds, or other conditions. In the interview results, several children under five had a history of other diseases such as inflammation and shortness of breath. This result can be further related to the symptoms of Acute Respiratory Infection (ARI) that many children experience when they are less than five years old and often affect their appetite. Thus, their intake and nutritional status are deficient. According to Mardiah's research in 2018, children under five not only experience one symptom complaint but three to five different complaints when experiencing ARI, and symptom grouping is based on complaints of ARI disease (Mardiah, 2018). According to the World Health Organization (WHO) in 2012, it was recorded that $78 \%$ of children under five experiencing ARI visited health services. Most parents, however, tended to ignore the symptoms; whereas, reciprocal interaction between infectious diseases 
Table 1. Characteristics of Families and Children

\begin{tabular}{|c|c|c|c|c|c|}
\hline \multirow{3}{*}{ Variable } & \multicolumn{4}{|c|}{ Nutritional Status (HAZ) } & \multirow{3}{*}{ p value } \\
\hline & \multicolumn{2}{|c|}{ Normal } & \multicolumn{2}{|c|}{ Stunting } & \\
\hline & $\mathbf{n}$ & $(\%)$ & $\mathbf{n}$ & $(\%)$ & \\
\hline \multicolumn{6}{|l|}{ Parent Characteristics } \\
\hline \multicolumn{6}{|l|}{ Father's Education } \\
\hline Graduated from high school & 85 & 51.24 & 77 & 46.38 & 0.060 \\
\hline Didn't graduate from high school & 4 & 2.40 & 0 & 0 & \\
\hline \multicolumn{6}{|l|}{ Mother's Education } \\
\hline Graduated from high school & 45 & 27.11 & 28 & 16.87 & 0.514 \\
\hline Didn't graduate from high school & 44 & 26.51 & 49 & 29.51 & \\
\hline \multicolumn{6}{|l|}{ Father's occupation } \\
\hline Work & 89 & 53.61 & 76 & 45.78 & 0.281 \\
\hline Does not work & 0 & 0 & 1 & 0.60 & \\
\hline \multicolumn{6}{|l|}{ Mother's work } \\
\hline Work & 23 & 13.65 & 13 & 7.83 & 0.162 \\
\hline Does not work & 66 & 39.75 & 64 & 38.55 & \\
\hline \multicolumn{6}{|l|}{ Family Income } \\
\hline High ( $\geq$ minimum wage) & 5 & 3.02 & 11 & 6.62 & 0.059 \\
\hline Low $(<$ minimum wage $)$ & 85 & 51.20 & 66 & 39.75 & \\
\hline \multicolumn{6}{|l|}{ Number of Family Members } \\
\hline Small family ( $\leq 4$ persons) & 44 & 26.50 & 77 & 46.38 & $<0,001^{*}$ \\
\hline Extended family ( $>4$ persons) & 45 & 27.01 & 0 & 0 & \\
\hline \multicolumn{6}{|l|}{ Parents' Marital Status } \\
\hline Married & 88 & 53.01 & 74 & 44.57 & 0.245 \\
\hline Ever been married & 1 & 0.60 & 3 & 1.80 & \\
\hline \multicolumn{6}{|l|}{ Under-five Children Caregivers } \\
\hline Mother & 59 & 35.54 & 68 & 40.96 & $0.001^{*}$ \\
\hline Other than Mother & 30 & 18.07 & 9 & 5.42 & \\
\hline \multicolumn{6}{|l|}{ Under-five Children Characteristics } \\
\hline \multicolumn{6}{|l|}{ Age (Month) } \\
\hline$<2$ Years & 25 & 15.06 & 1 & 0.60 & 0,238 \\
\hline$>2$ Years & 64 & 38.55 & 76 & 45.78 & \\
\hline \multicolumn{6}{|l|}{ Gender } \\
\hline Male & 35 & 21.08 & 39 & 23.49 & 0,748 \\
\hline Female & 54 & 32.53 & 38 & 22.89 & \\
\hline \multicolumn{6}{|l|}{ LBW } \\
\hline LBW & 10 & 6.02 & 6 & 3.61 & 0,239 \\
\hline Non LBW & 79 & 47.59 & 71 & 42.77 & \\
\hline
\end{tabular}

*Note: mean, average; SD, standard deviation; EIB, Early Initiation of Breastfeeding; LILA, the circumference of the upper arm; LIKA, head circumference; TB / U, height according to age; High school, high school. * The P-value is significant if $<0.05$.

and nutritional status, malnutrition will increase the risk of infection and infection can lead to malnutrition. If this happens for a long time and is not balanced with good nutrition, it will increase the risk of stunting (Mardiah, 2018).

Based on the results of statistical tests, children under five who often experience diarrhea are associated with the incidence of stunting, as indicated by the value of $p=0.023$. Similarly, children who had diarrhea in the last month also have a relationship with the occurrence of stunting with the value of $p=<0.001$. These results, moreover, are in line with the UNICEF conceptual framework, namely infectious diseases as one 
Table 2. Relationship between disease history and incidence of stunting

\begin{tabular}{|c|c|c|c|c|c|}
\hline \multirow{3}{*}{ Variable } & \multicolumn{4}{|c|}{ Nutritional status (HAZ) } & \multirow{3}{*}{ p-value } \\
\hline & \multicolumn{2}{|c|}{ Normal } & \multicolumn{2}{|c|}{ Stunting } & \\
\hline & $\mathbf{n}$ & $(\%)$ & $\mathrm{n}$ & (\%) & \\
\hline \multicolumn{6}{|c|}{ Frequently Suffered Diseases } \\
\hline Diarrhea & 24 & 14.45 & 8 & 4.81 & \multirow{3}{*}{0.023} \\
\hline Apart from diarrhea & 62 & 37.34 & 67 & 40.36 & \\
\hline Healthy & 3 & 1.8 & 2 & 1.2 & \\
\hline \multicolumn{6}{|c|}{ Disease during the Past Month } \\
\hline Diarrhea & 27 & 16.26 & 7 & 4.21 & \multirow{3}{*}{$<0.001$} \\
\hline Apart from diarrhea & 47 & 28.31 & 62 & 37.34 & \\
\hline Healthy & 15 & 9.03 & 7 & 4.21 & \\
\hline
\end{tabular}

of the direct causes of nutritional problems. In 2018, Rosiyanti studied several risk factors for stunting in Indonesia, Malaysia, Thailand, Laos, Myanmar, and Cambodia, and found that infectious disease factors, namely the incidence of diarrhea, affect the prevalence of stunting (Rosiyanti, 2018). Furthermore, as many as 6 million children die every year, especially in developing countries such as Indonesia (Indonesia MoH, 2013; WHO, 2012).

Acute diarrhea infection in children under five is associated with viral or bacterial acute gastroenteritis. Viruses causing diarrhea that are commonly found in children include rotavirus, norovirus, astrovirus, and several types of adenovirus. Rotavirus further releases enterotoxins that destroy intestinal mucosal enterocytes resulting in reduced absorption area, imbalance of secretion and absorption, and increased antiviral

Table 3. Relationship between Sanitation Facilities and Stunting

\begin{tabular}{lccccc}
\hline & \multicolumn{4}{c}{ Nutritional status } & \\
\cline { 2 - 4 } Variable & \multicolumn{2}{c}{ Normal } & \multicolumn{2}{c}{ Stunting } & p-value \\
\cline { 2 - 4 } & $\mathbf{n}$ & $\mathbf{( \% )}$ & $\mathbf{n}$ & $\mathbf{( \% )}$ & \\
\hline $\begin{array}{l}\text { Toilet Ownership } \\
\quad \text { Permanent }\end{array}$ & & & & & \\
$\begin{array}{l}\text { Healthy Toilet } \\
\text { Semi-Permanent }\end{array}$ & 78 & 46.98 & 70 & 42.17 & \\
$\begin{array}{l}\text { Healthy Toilet } \\
\begin{array}{l}\text { Public Toilet } \\
\text { Trash can }\end{array}\end{array}$ & 1 & 0.60 & 7 & 4.22 & \\
$\begin{array}{l}\text { Available, } \\
\text { Qualified }\end{array}$ & 33 & 19.88 & 45 & 27.11 & 0.006 \\
$\begin{array}{l}\text { Available, } \\
\text { Unqualified }\end{array}$ & 56 & 33.73 & 32 & 19.28 & \\
\hline
\end{tabular}

intestinal motility (Cooke, 2010). The result in diarrhea and dehydration (McCance et al., 2014). If this condition occurs for a long time and is not accompanied by adequate intake for the healing process, it will result in stunting (Indonesia $\mathrm{MoH}$, 2018).

The occurrence of diarrhea in children under five is influenced by environmental sanitation and poor personal hygiene behavior, as well as insufficient knowledge (WHO, 2013). Transmission of diarrhea is generally through the fecal-oral method, such as through food or drink contaminated by enteropathogens, or direct hand contact with sufferers or items that have been contaminated with patient feces or indirectly through flies (Bambang and Nurtjahjo, 2011). The process of transmission, moreover, includes washing cooking utensils using unclean water, drinking water that is not boiled first, and so on (Indonesia MoH, 2010).

Research by Abeng in 2014 concluded that children with poor environmental sanitation conditions or do not meet the requirements have the potential to suffer diarrhea by nine times higher (Abeng, 2014).

\section{Sanitation Facilities}

The results of the analysis identified that there was a relationship between toilet ownership and the incidence of stunting, indicated by $p=0.001$. In the sample group of children under five with stunting, 70 samples $(42.16 \%)$ used permanent healthy toilets, and seven respondents (4.21\%) still used public toilets. These findings further in line with the research carried out by Rohmah, explaining 
Table 4. Relationship Between Diarrhea, Sanitation Facilities and Stunting

\begin{tabular}{|c|c|c|c|c|c|c|}
\hline Variable & B & S.E & Sig & $\operatorname{Exp}(B)$ & \multicolumn{2}{|c|}{ CI 95\% } \\
\hline \multicolumn{7}{|l|}{ Frequently Suffered Diseases } \\
\hline \multicolumn{7}{|l|}{ Diarrhea } \\
\hline Apart from diarrhea & 0.483 & 0.93 & 0,029 & 1.621 & 0.262 & 10.027 \\
\hline \multicolumn{7}{|l|}{ Healthy } \\
\hline \multicolumn{7}{|l|}{ Disease during the Past Month } \\
\hline \multicolumn{7}{|l|}{ Diarrhea } \\
\hline Apart from diarrhea & 1.039 & 0.497 & 0.037 & 2.827 & 1.067 & 7.486 \\
\hline \multicolumn{7}{|l|}{ Healthy } \\
\hline \multicolumn{7}{|l|}{ Toilet Ownership } \\
\hline \multicolumn{7}{|l|}{ Permanent Healthy Toilet } \\
\hline Semi-Permanent Healthy Toilet & -2.054 & 1.082 & 0.058 & 0.128 & 0.015 & 1.168 \\
\hline \multicolumn{7}{|l|}{ Public Toilet } \\
\hline \multicolumn{7}{|l|}{ Trash bin } \\
\hline Available, Qualified & -0.87 & 0.319 & 0.006 & 0.419 & 0.224 & 0.783 \\
\hline Available, Unqualified & & & & & & \\
\hline
\end{tabular}

Note: B, koefisien beta; S.E, standar error; Sig, significant value; Exp (B), exponent value from B; CI, confident interval

that there is a significant relationship between the use of healthy toilets and the incidence of diarrhea (Rohmah, 2017). Research by Woldemicael in 2011 also revealed that toilet facilities increase the risk of stunting (Woldemicael, 2011). Improper fecal disposal behavior can increase the incidence of diarrhea because it can pollute the environment, mostly water, and soil around the place of residence (Rahman et al., 2016). Van der Hoek further stated that children who come from families that have clean water facilities have a lower prevalence of stunting than children who live with poor sanitation (Van der Hoek, 2014).

The use of water and soap in households is a contamination factor because children can ingest water that is contaminated with pathogens and is associated with the incidence of stunting (Corina, 2019). It is recorded that $34 \%$ of the diarrhea rate is higher in children whose households use open wells, which are used as sources of drinking water (Utami, 2015). Children under five who live with poor sanitation, thus, are more at risk of stunting because some stunted children under five have a place to live that does not meet the requirements for a healthy house, ventilation, lighting, and the availability of closed and watertight garbage dumps (Kusumawati, 2015). Those studies supported the results of the study, availability of qualified trash bin is associated with diarrhea $(\mathrm{p}=0.023)$.
Sanitation also plays a role as a factor in the prevalence of stunting because poor sanitation will increase the risk of illness in children under five. Sanitation does not meet the requirements, such as not having the supply of clean water for washing hands and food, or cleaning eating utensils will cause germs and bacteria that cause diarrhea alive. Water supply, additionally, is closely related to health; water contamination can lead to repeated infections (Cumming and Cairncross, 2016; Cronin et al., 2015).

Garbage in the trash bin more than $3 \times 24$ hours (3 days) can invite vectors, especially flies. The vector flies that are in the house due to the pile of garbage that are not thrown away can carry bacteria so that it is possible to land on the food to be consumed, which causes infectious diseases, namely diarrhea (Herawati, 2020).

Based on the regression test, it was found a positive relationship between a history of diarrhea and the incidence of stunting. Children under five who often experience diarrhea will have a 1.6 times risk of experiencing stunting and in the past month experiencing diarrhea, the risk of experiencing stunting is 2.8 times. In addition, sanitation factors have a negative relationship with the incidence of stunting, which means that families of under-five children who have healthy toilets will reduce the risk of stunting by 0.1 times. The existence of trash 
bins that meet the requirements will reduce the risk of children under five experiencing stunting by 0.4 times with a $95 \%$ CI value $(0.224 ; 0.78)$.

\section{CONCLUSION AND RECOMMENDATIONS}

There is no difference in the level of maternal education and maternal occupation between stunting and normal under-five children. Most of the mothers of the samples have completed their education up to high school. Most of the jobs of mothers are housewives, so mothers have a direct role in caring for children under five, which has a relationship with the incidence of stunting in under-five children. The number of family members divided into small and large families is also associated eith the prevalence of stunting.

Most of the under-five families, however, are classified as small families and have a total income below the minimum wage. Based on the results of this study, therefore, it can be concluded that the variable history of diarrhea is significantly associated with the incidence of stunting in children under five. In addition, environmental sanitation factors where children live, namely ownership of toilet and trash bin, also have a significant relationship with the incidence of stunting. Hence, it is necessary to increase the intensity of socialization and education regarding the importance of maintaining environmental cleanliness. Implementing education by regularly cleaning sanitation facilities and using them properly, to avoid bacterial contamination that can cause infectious diseases. The stunting prevention program shall more consider the awareness of the parents and their kids about nutrient intake, practice of hygiene and sanitation in the house.

\section{REFERENCE}

Adiyanti, M. (2014). Pola asuh gizi, sanitasi lingkungan, dan pemanfaatan posyandu dengan kejadian stunting pada baduta di Indonesia, Skripsi. Universitas Indonesia.

Astuti, F. D. (2013). Hubungan tingkat pendidikan ibu dan tingkat pendapatan keluarga dengan status gizi anak prasekolah dan sekolah dasar di kecamatan Godean. Jurnal Kesehatan Masyarakat, 7(1). Doi: 10.12928/kesmas. v7i1.1048
Azhar K. (2014). Pengaruh air minum terhadap kejadian penyakit. Bull. Penelitian Sistem Kesehatan, p. 107. Retrieved from https:// media.neliti.com/media/publications/20887-IDthe-influence-of-drinking-water-access-on-theoccurrence-of-water-borne-diseases.pdf

Bambang, S \& Nurtjahjo, B. S. (2011). Buku ajar gastroenterologi-hepatologi jilid 1,. Jakarta: UKK gasteroenterologi-hepatologi IDAI

Chen, M-F., Wang, R-H., Schneider, J. K., Tsai, C-T., Jiang, D.D.S., Hung, M-N., \& Lien, Li-Jen. (2011). Using the health belief model to understand caregiver factors influencing childhood influenza vaccinations. Journal of Community Health Nursing;28(1):29-40. PubMed. Doi: 10.1080/07370016.2011.539087

Cooke, M. (2010). Causes and management of diarrhoea in children in a clinical setting. $S$ Afr J Clin Nutr, 23(1): S42-S46. Doi: 10.1080/16070658.2010.11734269

Corina, \& Kwami S. (2019). Water, sanitation, and hygiene: linkages with stunting in Rural Ethiopia. International Journal of Environmental Research and Public Health, 16(20). 7. Doi: 10.3390/ijerph16203793

Cronin A, S. (2016). Association of safe disposal of child feces and reported diarrhea in Indonesia: Need for stronger focus on a neglected risk. International Journal Env. Res. Pub. Health, 13(3) p. 310. Doi: 10.3390/ijerph13030310

Cumming, V. C. (2018). Implications of WASH Benefits trials for water and sanitation. Lancet Glob. Health, 6(6) p. 613-e614. Doi: 10.1016/ S2214-109X(18)30225-0

Dinas Kesehatan Kota Surabaya. (2019). Profil Kesehatan Kota Surabaya Tahun 2018. Surabaya: Dinas Kesehatan Kota Surabaya.

Fikadu T, A. (2014). Factors associated with stunting among childen of age 24-59 months in Meskan district Gurage Zone, South Ethiopia : a case-control study. BMC public health, 14(1), 1-7. Doi: 10.1186/1471-2458-14-800

Herawati. (2020). Hubungan Sarana Sanitasi, Perilaku Penghuni, dan Kebiasaan Cuci Tangan Pakai Sabun (CTPS) oleh Ibu dengan Kejadian Pendek (Stunting) pada Batita Usia 6-24 Bulan di Wilayah Kerja Puskesmas Harapan Baru, Samarinda. Jurnal Kesehatan Lingkungan Indonesia, Vol 19 (1), Hal 7-15. Doi: 10.14710/ jkli.19.1.7-15

Indonesia MoH. (2010). Perilaku Hidup Bersih Dan Sehat, Jakarta: Depkes RI.

Indonesia MoH. (2013). Riset Kesehatan Dasar, Jakarta: Kementrian Kesehatan RI. 
Indonesia MoH.(2018). Situasi Balita Pendek(Stunting) di Indonesia Pusat Data dan Informasi Kementerian Kesehatan RI. Jakarta: Kemenkes RI.

Kementrian Kesehatan RI (2012). Pedoman Pengendalian Infeksi Saluran Pernafasan Akut. Jakarta: Kemenkes RI.

Kofuor E, D. (2014). A. Correlates of stunting among children in Ghana. BMC public health, 14(1), 1-7. Doi: 10.1186/1471-2458-14-504

Kusumawati. (2015). Model pengendalian faktor risiko stunting pada anak. Jurnal Kesehatan Masyarakat, Volume 9(3) 5-6.Doi:http://dx.doi. org $/ 10.21109 /$ kesmas.v9i3.572

Mardiah, W, Ati S M, \& Dyah S. (2018). Intervensi Perawatan Infeksi Saluran Pernafasan Atas pada Bayi dibawah Usia Lima Tahun di Rumah di Kabupaten Bandung. Jurnal Aplikasi Ipteks untuk Masyarakat, 7(4) 269-273. Doi:https:// doi.org/10.24198/dharmakarya.v7i4.19766

McCance, K.L., \& Sue,E.H.(2014).Pathophysiology: The biologic basis for disease in adults and children. Missouri: Elsevier Mosby.

Medhin, G., Hanlon, C., Dewey, M., Alem, A., Tesfaye, F., Worku, B., \& Tomlinson, M., Pronce, M. (2010). Prevalence and Predictors of Undernutrition Among Infants Age Six and Twelve Months In Butajira, Ethiopia: The P-MaMiE Birth Cohort. BMC Public Health, 10:27. Retrieved from https://bmcpublichealth. biomedcentral.com/articles/10.1186/14712458-10-27

Murtiana, A., Setiyajati, A., \& Bahri, A.S. (2014). Hubungan faktor sosiodemografi dengan kejadian diare pada balita di wilayah kerja Puskesmas Giriwoyo 1 Wonogiri. Jurnal Ilmu Keperawatan Indonesia, 7 (2). Retrieved from https://ppjp. ulm.ac.id/journal/index.php/berkala-kesehatan/ article/download/5071/4361

Nafi'ah, S. (2015). Gambaran Karakteristik Ibu Balita Yang Memiliki Gizi Kurang Di Desa Sambungwangan Kecamatan Randublatung Kabupaten Blora. Skripsi. Stikes Ngudi Waluyo. Doi: https://doi.org/10.36474/caring.v3i1.101

PUSDATIN. (2016). Situasi Imunisasi di Indonesia. Jakarta: Kementerian Kesehatan

Patunru, A. (2015). Access to safe drinking water and sanitation in Indonesia Asia Pacific. Policy Study, 2 (2), 234-244. Doi: https://doi. org/10.1002/app5.81

Rahman, H. F, Widoyo S, Siswanto H, \& Biantoro. (2016). Faktor-Faktor Yang Berhubungan dengan Kejadian Diare di Desa Solor Kecamatan Cermee Bondowoso. NurseLine Journal, 1(1),
24-35. Doi: https://doi.org/10.33024/jikk. v7i2.2738

Roscha, B.C., Putri, B.S.K., \& Putri, I.Y.S. (2013). Determinan status gizi pendek anak balita dengan riwayat berat badan lahir rendah (BBLR) di Indonesia (Analisis Data Riskesdas 2007-2010). Jurnal Ekologi Kesehatan, 12(3), 195-205. Retrieved from http://ejournal. litbang.kemkes.go.id/index.php/jek/article/ download/3866/3716

Rosiyati, Eka P, Erlina AD, Poristinawati I. (2018). Faktor Determinan yang Mempengaruhi Stunting pada Anak (usia 0-59 Bulan) di Beberapa Negara Asia Tenggara. Jurnal Kesehatan Komunitas, p. Vol 4 No 3. Doi: https://doi.org/10.25311/ keskom.Vol4.Iss3.262

Setyawati. (2018). Stunting Anak Usia Sekolah Menurut Karakteristik Keluarga. Penelitian Gizi dan Makanan , 36 : 121-126. Retrieved from http://ejournal. litbang.kemkes.go.id/index.php/ pgm/article/ download/3997/3814

Sulastri, D. (2012). Faktor derteminan kejadian stunting pada anak sekolah di kecamatan lubuk kilang kota padang. Majalah kedokteran andalas, 29(1), 39-50. Doi: https://doi.org/10.22338/ mka.v36.i1.p39-50.2012

UNICEF. (2013). Improving Child Nutrition: The achievable imperative for global progress. New York: United Nations Children Fund

Utami S, S. K. H. (2015). The Effect of Improved Water Supply on Diarrhea Prevalence of Stunting. Jurnal Aplikasi Ipteks, Vol 7. No 1.

Van der, H. W, Feenstra S.G, Konradsen F. (2014). Avaibility of irrigation water for domestic use in Pakistan: its impact on prevalence of diarrhoe and nutritional status of children. Journal of health population and nutrition status of children, 20: 77-84. Retrieved from http://citeseerx.ist.psu. edu/messages/downloadsexceeded.html

WHO. (2013). Diarrhoeal disease. Geneva: WHO Available at : http://www.who.int/mediacentre/ factsheets/fs330/en/

Woldemicael G. (2011). Diarrhoea morbidity among young children in Eritrea: environmental and socioeconomic determinants. $J$ Health Populat Nutr, 19(2):83-90. Retrieved from https://www.panafrican-med-journal.com/ content/article/38/391/pdf/391.pdf

Zairinayati, Rio P. (2019). Hubungan dan Sanitasi Lingkungan dengan Kejadian Stunting pada Balita. Jurnal Ilmiah Multi Science Kesehatan. Vol 10 (1) hal 78-91. Doi:https:// doi.org/10.36729/bi.v10i1.186 